\title{
REKONTEKSTUALISASI SEJARAH : KONTRIBUSI LEMBAGA PENDIDIKAN ISLAM TERHADAP DAKWAH RASULULLAH SAW
}

\author{
Musaddad Harahap \\ (Universitas Islam Riau) \\ Lina Mayasari Siregar \\ (STAI Barumun Raya Sibuhuan)
}

\begin{abstract}
Abstrak:
Tulisan ini mencoba menyelami kesuksesan Nabi Muhammad SAW dalam merangkai ajaran-ajaran Islam menjadi satu kesatuan yang utuh lewat pendidikan. Selama kurun 23 tahun Islam sudah menjadi ajaran yang mapan penuh dengan rahasia keilmuan, sehingga Islam dijuluki sebagai agama yang rahmatallil'alamin. Dengan pendekatan studi pustaka, penelitian ini memaparkan keberhasilan Nabi SAW dalam menyampaikan risalah kenabian yang sangat didukung oleh tempat-tempat yang representatif dalam mengajarkan pada waktu itu. Tempat-tempat yang dimaksud telah mengalami akulturasi budaya sebelum datangnya isalm dan terus berkembang bersamaan kedatangan Islam itu sendiri. Mengenai tempat yang berakultrasi dengan Islam adalah kuttab dan rumah, sementara yang tumbuh bersama dengan Islam itu sendiri adalah masjid dan suffah. Keempat lembaga pendidikan Islam yang disebutkan menjadi saluran utama yang digunakan Nabi SAW dalam mendidik para sahabatnya. Dengan demikian dapat disimpulkan bahwa Islam adalah agama yang peduli dengan pendidikan dan sangat fleksibel terhadap kondisi dan situasi bagaimana agar proses pendidikan itu dapat berjalan. Kontribusi lembaga pendidikan Islam selain mampu menciptakan perubahan mendasar dalam konteks keagamaan dan kehidupan sosial juga menjadikan Islam sebagai agama yang terbuka (inkulsif) terhadap perubahan sosial selama tidak bertetangan dengan aqidah.
\end{abstract}

Kata Kunci: Lembaga; Pendidikan Islam; Dakwah; Rasulullah SAW. 


\begin{abstract}
:
This paper attempts to examine the success of Prophet Muhmmad PBUH in arranging Islamic teachings into a set through education. Within 23 years, Islam emerged into an established teaching and full of hidden knowledge, making Islam gets predicate of blessing for the universe. Through literary study, this research explains the success of the prophet in delivering prophetic messages with support of representative teaching places at the period. The places acculturated with the coming of Islam and keep growing along with the development of Islam. Kuttab and house has acculturated with Islam and Mosques and Suffah have grown together with Islam. The four kind of places became main channels for the prophet PBUH in educating his companions. Therefore, it can be concluded that Islam is a religion with high education concerns and quite flexible towards condition and situation where the educational process takes place. Islamic educational institution is not only creating fundamental change in religious and social life, but also making Islam as an inclusive religion to social changes as long as the changes are not contradictory to Islamic faith.
\end{abstract}

\title{
Keywords: Institution; Islamic Education; Missionary; Prophet PBUH.
}

\section{A. Pendahuluan}

Pada masa sekarang, pendidikan Islam secara kuantitatif cukup membagakan. Tetapi secara kualitatif pendidikan Islam bila dibandingkan dengan pendidikan diluarnya masih jauh tertinggal agak dibelakang. Keadaan semacam ini agak dilematis, sebab peningkatan jumlah lembaga pendidikan Islam tidak serta merta dapat meningkatkan kualitas pendidikan Islam itu sendiri. Kesenjangan ini tampaknya hampir dirasakan oleh setiap negara-negara muslim di mana lembaganya banyak tetapi masih jauh tertinggal dengan negaranegara yang notabenenya bukan muslim.

Sebagai bukti belum maksimalnya peningkatan kualitas di lembagalembaga pendidikan Islam, dapat dilihat fenomena arus pengiriman pelajarpelajar muslim ke Eropa. Ketika para pelajar ini kembali ke tanah air sampai saat ini orang-orang tersebut masih menjadi trend dikalangan masyarakat. Hal ini membuktikan paradigma masyarakat terhadap alumni eropa atau negara-negara maju masih tetap mengalahkan alumni dalam negeri. Bahkan Negara pun biasanya jauh lebih memprioritaskan alumni-alumni Negara maju tersebut dibandingkan alumni dalam negeri. Berdasarkan hal ini dapat dipahami bahwa lembaga pendidikan Islam belum mampu mencapai level lembagan-lembaga pendidikan di Negara-negara maju terutama berkaitan dengan ilmu-ilmu eksak.

Tetapi Islam harus tetap optimis, bahwa ketertinggalan itu pasti dapat dituntaskan. Sebab Islam memiliki ajaran yang sangat kaya, bahkan Nabi 
Muhammad SAW telah membuktikan bahwa Islam dengan waktu 23 tahun mampu merevoluasi total kehidupan umat Manusia. Dengan semangat yang luar biasa umat Islam mampu keluar menjadi icon peradaban umat manusia.

Seperti diketahui bahwa Nabi adalah Sang Revolusioner yang lahir pada hari Senin, 12 Rabiul Awwal 571 M dari pasangan suami isteri yakni Abdullah dan Aminah. Muhammad dilahirkan dari kalangan suku Quraisy, sebuah suku terhormat dari keturunan Ismailiyah. Salah satu keturunan Ismail terdapat seorang yang berkuasa bernama Fhir yang nama lainnya adalah Quraisy. Pada abad kelima masehi, salah seorang keturunan Quraisy yang bernama Qusay berhasil menyatukan suku-suku Quraisy yang bertempat tinggal di Hijaj dan menjadi penguasa Ka'bah. ${ }^{1}$

Dalam sejarah peradaban Islam Nabi Muhammad SAW disebutkan wafat pada tahun $632 \mathrm{M}$ dengan usia \pm 63 tahun. Rentang waktu 63 tahun ini adalah masa-masa paling sejarah bagi dunia Islam. Rentang waktu ini ibarat sumber mata air yang tidak ada henti-hentinya untuk mengalir, termasuk di dalamnya kajian-kajian tentang pendidikan Islam. Bagi siapapun yang ingin menekuni konsep pendidikan Islam tentulah harus merujuk kepada masa perjuangan tersebut. Namun tetap harus disadari seperti disebutkan Roqib ${ }^{2}$ bahwa konsep pendidikan Islam yang terkandung dimasa hidup Nabi Muhammad SAW amatlah luas karena menyangkut berbagai bidang yang berkaitan dengan pendidikan itu sendiri, sehingga dalam kajian ini pun hanya dibatasi pada bagaimana model lembaga pendidikan yang ada pada Nabi Muhammad SAW.

Penentuan pokok persoalan ini didasari oleh suatu pemikiran bahwa perjuangan dan keberhasilan pada masa awal Islam adalah benar-benar sumber inspirasi. Berkenaan dengan keberhasilan yang dicapai Nabi Muhammad SAW dalam perspektif pendidikan tentulah tidak berdiri sendiri, tetapi banyak hal yang mendukung, termasuk bagaimana sarana yang digunakan sehingga risalah Ilahiyah yang diembannya benar-benar terwujud.

Oleh karena itu, dengan pengkajian terhadap aktivitas-aktivitas pendidikan di masa awal ini, diharapkan dapat menyegarkan kembali ingatan kita tentang bagaimana sosok Nabi Muhammad SAW dapat berhasil membentuk dan membina manusia yang sebelumnya telah mengalami krisis di berbagai lini kehidupan.

\footnotetext{
${ }^{1}$ Lina Mayasari Siregar, "Upaya Pendidikan Islam pada Masa Awal Nabi Muhammad SAW," AlThariqah: Jurnal Pendidikan Agama Islam, Vol. 1, No. 1 (2017), 104-114.

2 Moh. Roqib, Ilmu Pendidikan Islam; Pengembangan Pendidikan Integratif di Sekolah, Keluarga, Masyarakat (Yokyakarta: LKiS, 2009), 4.
} 


\section{B. Lembaga Pendidikan Islam; Interaksi Edukatif Dakwah Rasulullah}

Dewasa ini pengertian lembaga pendidikan Islam cukup banyak yang ditawarkan oleh para tokoh-tokoh, yang satu dengan lainnya tidak jarang terjadi perbedaan diakibatkan cara pandang dan pendekatan yang berbeda. Dalam bahasa Inggris, lembaga disebutkan dengan institution. Sedangkan dalam Kamus Besar Bahasa Indonesia (KBBI) diartikan dengan badan (organisasi) yang tujuannya melakukan suatu penyelidikan keilmuan atau melakukan suatu usaha. $^{3}$ Lembaga menurut pengertian etimologi adalah badan acuan atau organisasi yang diadakan dalam upaya menyelenggarakan upaya-upaya penelitian keilmuan, baik bersifat formal, seperti madrasah, maupun non formal seperti pengajian dan kursus keagamaan. ${ }^{4}$

Enung K. Rukiati dan Feki Rukianti, mendefenisikan lembaga pendidikan sebagai suatu wadah atau tempat berlangsungnya proses pendidikan dan proses pembudayaan. Proses tersebut dimulai dari lingkungan keluarga. Sementara Hasan Langgulung mengatakan bahwa lembaga pendidikan adalah sistem yang terus menerus berlangsung atau konsep yang terdiri dari norma atau ideologi dan organisasi simbolik yang terdiri dari kelompok manusia yang dibentuk secara sengaja atau tidak mencapai tujuan tertentu. ${ }^{5}$

Dari beberapa defenisi di atas dapatlah dipahami bahwa lembaga pendidikan Islam itu adalah sebuah norma yang tersistem dan terorganisasi yaitu tempat berlangsungnya penyelenggaraan pendidikan Islam. Ungkapan di atas jelas mengisyaratkan makna secara eksplisit yaitu: Pertama, lembaga adalah sebuah norma (pranata sosial) dan serangkaian sistem yang dibentuk untuk menanamkan nilai luhur pendidikan. Hal ini dapat juga diartikan sebagai nonomateril atau abstrak. Kedua, lembaga diartikan sebagai tempat atau forum berlangsungnya proses pendidikan konkrit atau materi.

Definisi yang memiliki makna eksplisit di atas merupakan salah satu ladasan pengoperasionalan pendidikan dewasa ini. Tetapi pertanyaannya apakah definisi itu telah mumpuni untuk dijadikan landasan dalam pengoperasionalan pendidikan Islam itu? Maka sebagai usaha yang paling efektif untuk menjawab persoalan itu adalah memfokuskan kembali secara serius menggali dan mengkaji bagaimana lembaga pendidikan Islam di masa awal.

\footnotetext{
${ }^{3}$ Pengertian lembaga dalam kamus KBBI sebetulnya memiliki pengertian yang cukup bervariasi, salah satunya disebut sebagai tempat yang dalam hal ini erat kaitannya dengan pendidikan. Lihat Departemen Pendidikan Nasional, Kamus Besar Bahasa Indonesia (Jakarta: Pusat Bahasa, 2008), 904.

${ }^{4}$ Ramayulis, Ilmu Pendidikan Islam (Jakarta: Kalam Mulia, 2006), 227.

${ }^{5}$ Hasan Langgulung, Asas-asas Pendidikan Islam (Jakarta: Pustaka al-Husna, 1992), Cet. II, 121.
} 
Masa awal sejarah Islam yang ditandai dengan majunya Nabi Muhammad ke tengah-tengah manusia untuk mengajak beriman kepada Allah dengan segala term-termnya dan ajarannya yang sudah terhimpun dalam al-Qur'an dan Hadis/Sunnah adalah satu-satunya modal untuk mengetahui lembaga yang bagaimana sepatutnya dijadikan sebagai lembaga pendidikan Islam.

Namun, apabila diperhatikan dalam al-Qur'an sesungguhnya tidak ada ditemukan term khusus tentang lembaga pendidikan, akan tetapi secara implisit setidaknya ada dua lembaga yang terekam dalam al-Qur'an yaitu rumah dan masjid. Hal ini diperkuat dalam sejarah Islam kedua bentuk lembaga ini pernah menjadi tonggak pernjuangan oleh Nabi Muhammad dan para sahabat masa itu yang di dalamnya pernah terjadi interaksi edukatif. ${ }^{6}$ Melalui interaksi edukatif ini juga adalah sebuah pertanda bahwa Nabi telah memainkan peran pendidikan dalam menempa peserta didik (sahabat), baik jasmani mapun rohaninya sehingga pada waktu itu manusia yang mulanya mensekutukan Allah kembali kepada fithrahnya yaitu mengagungkan Allah. Jadi untuk lebih jelasnya kedua lembaga ini akan dikupas pada bagian berikut.

\section{Rumah Tangga sebagai Fondasi Dasar Pendidikan Islam}

Keluarga adalah Sebagai Lembaga Pendidikan Islam dalam Islam, keluarga dikenal dengan istilah usrah, nasl, 'ali, dan nasb. Keluarga dapat diperoleh melalui keturunan (anak, cucu), perkawinan (suami, istri), persusuan, dan pemerdekaan.7 Keluarga merupakan wadah pertama bagi anak dalam mendapatkan bimbingan agama.

Pendidikan agama ialah pendidikan yang mencakup penanaman nilainilai keagamaan dengan ajaran agama dan kepercayaan masing-masing. Pendidikan agama harus ditanamkan pada anak sedini mungkin, bahkan saat anak masih dalam kandungan. Dalam pandangan Islam, manusia lahir dengan membawa fitrah keagamaan yang harus dikembangkan lebih optimal lagi, yaitu oleh orang tua sebagai pendidik pertama dan utama, agar menjadi manusia yang beriman dan bertakwa pada Tuhan-nya. ${ }^{8}$

Selain dari pada itu di masa Nabi Muhammad periode Makkah memang rumah tangga sudah dijadikan lembaga pendidikan yang sifatnya masih sederhana. Semenjak awal-awal turunnya wahyu kepada Nabi Muhammad SAW rumah al-Arqam bin Abi al-Arqam merupakan lembaga pendidikan pertama.

\footnotetext{
${ }^{6}$ Musaddad Harahap, "Esensi Peserta Didik dalam Perspektif Pendidikan Islam," Al-Thariqah: Jurnal Pendidikan Agama Islam, Vol. 1. No. 2 (2017), 140-155.

${ }^{7}$ Abdul Mujib dan Jusuf Mudzakkir, Ilmu Pendidikan Islam (Jakarta: Kencana: 2008), 231.

8 Mufatihatut Taubah, "Pendidikan Anak dalam Keluarga Perspektif Islam," Jurnal Pendidikan Agama Islam (Journal of Islamic Education Studies), Vol. 3 No. 1 (2016), 109-136.
}

Jurnal Pendidikan Agama Islam (Journal of Islamic Education Studies)

Volume 5 Nomor 2 (2017)

ISSN(p) 2089-1946\& ISSN(e) 2527-4511

Hal. 292 - 308 
Pendidiknya adalah Nabi SAW sendiri dengan mengumpulkan para sahabat untuk diajarkan ayat-ayat al-Qur'an yang diturunkan oleh Malaikat Jibril. Di rumah Arqam ini juga Nabi SAW menerima tamu dan orang yang hendak masuk Islam atau menanyakannya. Selain dari pada itu Nabi SAW juga mengajarkan agama Islam di rumah beliau sendiri. ${ }^{9}$ Maka jelaslah rumah memang betul-betul menjadi lembaga pendidikan yang utama, karena itu artinya dalam keluarga pendidikan akan berlangsung sebagaimana yang sudah di definisikan di atas.

Pentingnya serta keutamaan rumah tangga sebagai lembaga pendidikan Islam telah disyaratkan dalam Al-Quran surah at-Tahrim ayat 6:

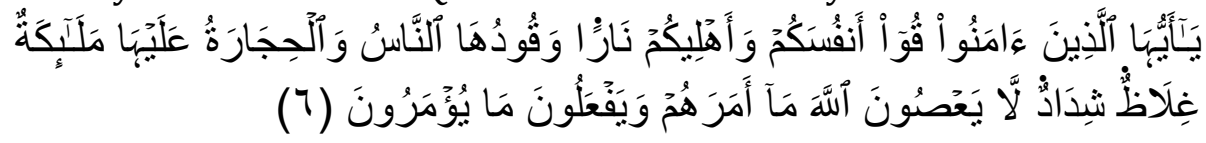

"Hai orang-orang yang beriman, peliharalah dirimu dan keluargamu dari api neraka yang bahan bakarnya adalah manusia dan batu; penjaganya malaikatmalaikat yang kasar, keras, dan tidak mendurhakai Allah terhadap apa yang diperintahkan-Nya kepada mereka dan selalu mengerjakan apa yang diperintahkan.

Ayat ini adalah sebuah seruan dari Dzat Yang Maha Agung kepada orangorang yang beriman, berisi perintah dan peringatan berikut kabar tentang bahaya besar yang mengancam. Seruan ini ditujukan kepada insan beriman, karena hanya mereka yang mau mencurahkan pendengaran kepada ajakan Allah Subhanahu wa Ta'ala, berpegang dengan perintah-Nya dan mengambil manfaat dari ucapan-Nya. Allah Subhanahu wa Ta'ala perintahkan mereka agar menyiapkan tameng untuk diri mereka sendiri dan untuk keluarga mereka guna menangkal bahaya yang ada di hadapan mereka serta kebinasaan di jalan mereka. Bahaya yang mengerikan itu adalah api yang sangat besar, tidak sama dengan api yang biasa kita kenal, yang dapat dinyalakan dengan kayu bakar dan dipadamkan oleh air. Api neraka ini bahan bakarnya adalah tubuh-tubuh manusia dan batu-batu. Ia berbeda sama sekali dengan api di dunia. Bila orang terbakar dengan api dunia, ia pun meninggal berpisah dengan kehidupan dan tidak lagi merasakan sakitnya pembakaran tersebut, tapi api neraka akan terasa untuk selamanya karena kehidupan akhirat itu adalah kehidupan abadi. Seperti dijelaskan dalam surah Al-Isra' ayat 97, yaitu:

${ }^{9}$ Hasan Asari, Hadis-hadis Pendidikan; Sebuah Penelusuran Akar-akar Ilmu Pendidikan Islam (Bandung: Cita Pustaka, 2008), 99. 


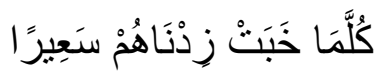

"Setiap kali nyala api Jahannam itu akan padam, Kami tambah lagi nyalanya bagi mereka."

Jika diperhatikan dalam tafsir al-Maraghi tentang ayat ini dijelaskan bahwa setiap manusia disuruh untuk membuat perlindungan agar tidak terbakar oleh api, perlindungan yang dimaksud itu termasuk meninggalkan maksiat. Sedangkan menjaga keluarga dari api neraka Al-Maraghi menafsirkannya dengan cara mecegahkan mereka sikap yang sopan serta memberinya nasehat-nasehat, baik isteri, anak, pembantu dan sebagainya. ${ }^{10}$

Dari penjelasan yang terdapat dalam tafsir Al-Maraghi tersebut terlihat jelas bahwa interaksi yang diajarkan antara seseorang dengan keluarga merupakan proses pendidikan. Sementara bila diamati lebih lanjut yang dinamakan keluarga itu dimulai dari rumah tangga yang di dalamnya hidup manusia tiga posisi yang berbeda-beda yaitu suami, isteri dan anak. Ketiga komponen ini saling berintekrasi satu sama lain. Namun yang dominan pengaruhnya adalah orang tua, merekalah pendidiknya yang dalam hal ini mendidik anak-anak mereka untuk taat kepada Allah.

Urgensi menjaga diri dan keluarga dari api neraka adalah bentuk pendidikan yang sangat tepat. Itu artinya antara sesama keluarga harus saling nasehat menasehati agar tidak terjerumus dalam maksiat, sebab maksiat itu adalah perilaku yang tidak disukai Allah SWT. Dalam surah al-'Asr ayat 3 dijelaskan:

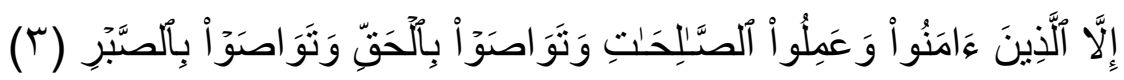
“...nasehat menasehati supaya mentaati kebenaran dan nasehat menasehati supaya menetapi kesabaran..."

Kemudian keluarga itu sebagai lembaga pendidikan pertama yang mempengaruhi perkembagan anak sangat ditentukan oleh pengelola lembaga, hal ini tentu orang tua. Maka orang tua itu besar peranannya untuk membuka peluang masuk atau tidaknya anggota keluarga kepada ancaman Allah sepert yang dijelaskan dalam surah at-Tahrim ayat 6 di atas. Dalam sebuat hadis dijelaskan:

“Telah menceritakan kepada kami Hajib bin Al Walid telah menceritakan kepada kami Muhammad bin Harb dari Az Zubaidi dari Az Zuhri telah mengabarkan kepadaku Sa'id bin Al Musayyab dari Abu Hurairah, dia berkata; "Rasulullah shallallahu 'alaihi wasallam telah bersabda: 'Seorang bayi tidak dilahirkan (ke

\footnotetext{
${ }^{10} \mathrm{Ahmad}$ Mustafa al-Maraghi, Tafsir Al-Maraghi, Juz 28 (Mesir: Syirkatu Maktabah, 1946), 161.

Jurnal Pendidikan Agama Islam (Journal of Islamic Education Studies)

Volume 5 Nomor 2 (2017)

ISSN(p) 2089-1946\& ISSN(e) 2527-4511

Hal. 294 - 308
} 
dunia ini) melainkan ia berada dalam kesucian (fitrah). Kemudian kedua orang tuanyalah yang akan membuatnya menjadi Yahudi, Nasrani, ataupun Majusi."11

Dari hadis di atas, jelaslah bahwa manusia dilahirkan dalam keadaan fitrah. Hadis di atas memberikan petunjuk kepada keluarga sebagai lembaga pertama yang berperan dalam menanamkan pendidikan kepada anak. ${ }^{12}$

Oleh sebab itu, orang tua sebagai pendidik memiliki kewajiban yang besar atas anak-anaknya. Dalam hal ini ayah dan ibu memiliki kewajiban, tapi kewajiban keduanya memilik perberbedaan karena keduanya berbeda kodrat. Ayah berkewajiban mencari nafkah untuk mencukupi kebutuhaan keluarganya melalui pemanfaatan karunia Allah SWT di muka bumi sebagaimana dijelaskan dalam QS. Al-Jumu'ah : 10 dan selanjutnya dinafkahkan pada anak istrinya (QS. al-Baqarah: 228, 233). Kewajiban ibu adalah menjaga, memelihara dan mengelola keluarga di rumah suaminya, terlebih lagi mendidik dan merawat anaknya. Sebagai pendidikan yang pertama dan utama, pendidikan keluarga dapat mencetak anak agar mempunyai kepribadian yang kemudian dapat dikembangkan dalam lembaga-lembaga berikutnya, sehingga wewenang lembaga-lembaga tersebut tidak diperkenankan mengubah apa yang telah dimilikinya, tetapi cukup dengan mengombinasikan antara pendidikan yang diperoleh dari keluarga dengan pendidikan lembaga tersebut, sehingga masjid, pondok pesantren dan sekolah merupakan tempat peralihan dari pendidikan keluarga. ${ }^{13}$

Kewajiban untuk mencegah dan memelihara diri dan keluarga dari api neraka berati belajar serta memberikan pelajaran. Maka bisa dipastikan rumah tangga itu adalah lembaga untuk melaksana proses belajar dan mengajar.

Kemudian pendidikan dalam rumah tangga lainnya dapat ditemukan dalam surah Luqman ayat 13 yaitu:

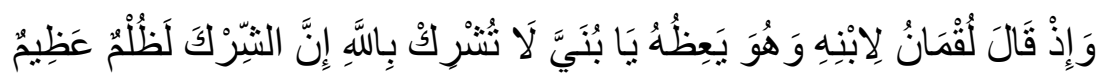

"Dan (ingatlah) ketika Luqman berkata kepada anaknya, diwaktu ia memberiakan pelajaran kepadanya: "Hai anakku, janganlah kamu mempersekutukan Allah, sesungguhnya merpersekutuan (Allah) adalah benarbenar kezaliman yang besar".

Mempersekutukan Allah dikatakan kelaliman, karena perbuatan itu berarti menempatkan sesuatu tidak pada tempatnya, yaitu menyamakan sesuatu

\footnotetext{
${ }^{11}$ Hadiyah Salim, Terjemahan Mukhtarul Hadits Sayyid Ahmad Al-Hasyimi (Bandung: Al-Ma'arif, 1980), 592.

12 Asari, Hadis-hadis Pendidikan, 100.

${ }^{13}$ Muhammad Yusuf al-Hasan, Pendidikan Anak dalam Islam (Jakarta: Kalam Mulia, 2001), 57.
} 
yang melimpahkan nikmat dan karunia itu. Dalam hal ini menyamakan Allah SWT sebagai sumber nikmat dan karunia dengan patung-patung yang tidak dapat berbuat sesuatupun. Dikatakan bahwa perbuatan itu adalah kelaliman yang besar, karena yang disamakan itu ialah Allah Pencipta dan Penguasa semesta alam, yang seharusnya semua makhluk mengabdi dan menghambakan diri kepada Nya. ${ }^{14}$

Maka pantas seorang Luqman yang memiliki pengetahuan tinggi dan orang yang taat kepada Allah melarang anaknya melakukan syirik. Larangan ini adalah suatu yang memang patut di sampaikan Luqman kepada putranya karena mengerjakan syirik itu benar-benar menyalahi kodrat penciptaan manusia. Iman yang sebenarnya hanyalah kepada Allah.

Oleh karena itu, dapat disimpulkan bahwa menanamkan pendidikan keimanan kepada anak, merupakan modal dasar mereka meraih kesuksesan dunia dan akhirat sekalipun menanamkan iman ke dalam hati anak-anak memang sangat sulit diidentifikasi. Meskipun demikian, apa yang dilakukan Nabi dalam menanamkan iman kepada keluarganya dan para sahabat pada priode Mekkah dapat dijadikan sebagai petunjuk.

Mengingat pentingnya pendidikan iman ini bagi anak maka orang tua harus memperioritaskannya dalam lembaga pendidikan rumah tangga yang transformasinya mencakup keyakinan kepada Allah, Malaikat Allah, Kitab suci, Rasul-Nya, hari kiamat, qada dan qadar sangat penting. Ini jugalah salah satu upaya keluarga untuk memelihara diri dan keluarga sebagaimana dalam surah at-Tahrim ayat 6 yang disebut di awal.

1. Menanamkan keyakinan kepada Allah SWT

Menanamkan keimanan kepada Allah dimaksudkan untuk mengenalkan kepada anank-anak siapa pencipta, pemelihara, pemberi rizki, pengatur, sesembahan yang benar-benar boleh disembah oleh manusia, ditaati perintah-Nya, dijauhi segala larangan-Nya, dimintai pertolongan, dan tempat manusia mempertanggungjawabkan segala perbuatan selama di dunia ini. ${ }^{15}$ konsepsi tentang Ketuhanan ini disebut Tauhid. ${ }^{16}$

2. Menanamkan keyakinan anak kepada Malaikat-Malaikat

Orang tua yang mengajarkan kepada anak bahwa beriman kepada malaikat mempunyai konsekuensi. Konsekuensinya, agar manusia (anak)

\footnotetext{
${ }^{14}$ Ja'far Muhammad bin Jarir at-Thabari, Tafsir al-Thabari Juz Atssaminu 'Asyara (Badar Hijr: Ath-Taba'ah wa al-Nasir wa al-Taji'u wa al-I'lan, 2001), 549-550.

15M. Thalib, 50 Pedoman Mendidik Anak Menjadi Shalih (Bandung: Irsyad Baltus Salam, 1996), 349-350.

16Mohammad Daud Ali, Pendidikan Agama Islam (Jakarta: Raja Grafindo Persada, 1998), 202.

Jurnal Pendidikan Agama Islam (Journal of Islamic Education Studies)

Volume 5 Nomor 2 (2017)

ISSN(p) 2089-1946\& ISSN(e) 2527-4511

Hal. 296 - 308
} 
meyakini adanya kehidupan rohani yang harus dikembangkan sesuai dengan dorongan para malaikat itu. ${ }^{17}$

3. Menanamkan keyakinan kepada kitab suci

Al-Qur'an merupakan sumber utama ajaran Islam. Menurut keyakinan umat Islam yang dibenarkan oleh penelitian ilmiah, Al-Qur'an adalah kitab suci yang memuat firam-firman Allah berupa wahyu yang disampaikan oleh malaikat Jibril kepada Nabi Muhammad sebagai Rasulullah sedikit demi sedikit selama 22 tahun 2 bulan 22 hari, mula-mula di Mekah, kemudian di Madinah. ${ }^{18}$

4. Menanamkan keyakinan kepada Rasul-Nya

Nabi Muhammad adalah Nabi penutup segala Nabi, Rasul terakhir. Sejarah hidupnya jelas dan lengkap serta terpelihara dari masa ke masa. Akhlaknya baik, yang biasanya digambarkan dengan kata-kata (1) dapat dipercaya (amanah); (2) selalu benar (siddiq); (3) cerdas dan bijaksana (fatanah); (4) selalu menyampaikan yang harus disampaikannya (tabligh). ${ }^{19}$ Akhlak baik para Nabi dan Rasul yang terhimpun dalam empat kata kunci di atas sangatlah penting bagi seorang anak. Maka orang tua harus mampu menanamkan nilai-nilai itu kepada anak.

5. Menanamkan keyakinan kepada hari kiamat

Menurut Abdul A'la Maududi seperti yang dikutip Mohammad Daud Ali, bahwa manusia tidak dilepaskan begitu saja ke dunia ini sebagai binatang yang tidak bertanggung jawab. Ia betanggung jawab atas segala perbuatannya dan harus mempertanggung jawabkan perbuatannya itu kepada Allah kelak, yakni setelah hari kiamat, sesudah kehidupan manusia di atas bumi ini berakhir dan berganti dengan kehidupan lain. ${ }^{20}$ Ketika anak memiliki kesadaran bahwa hari kiamat pasti adanya, maka diharapkan akan membawa mereka untuk selalu berbakti kepada Allah dan akan menampilkan sikap positif baik sesama manusia, kepada makhluk hidup lain, juga terhadap lingkungan mereka.

6. Menanamkan keyakinan kepada qada dan qadar

Wajib bagi orang tua menanamkan pendidikan qada dan qadar kepada anak , supaya anak meyakini bahwa Allah Mahakuasa serta memiliki wewenang penuh untuk menurunkan ketentuan apa saja bagi makhluk-Nya. ${ }^{21}$ Demikian juga setiap orang tua untuk selalu mengajari anak-anak mereka

\footnotetext{
${ }^{17}$ Ali, Pendidikan Agama Islam, 210.

${ }^{18}$ Ali, Pendidikan Agama Islam, 217.

${ }^{19}$ Ali, Pendidikan Agama Islam, 225.

${ }^{20}$ Ali, Pendidikan Agama Islam, 226-227.

${ }^{21}$ Ali, Pendidikan Agama Islam, 134.
} 
untuk meyakini sepenuhnya bahwa manusia diberi kebebasan memilih dan menentukan nasibnya sendiri dengan segala kemampuan usahanya serta doanya kepada Allah.

\section{Masjid sebagai Pusat Pendidikan Islam}

Masjid adalah rumah tempat ibadah umat Muslim. Masjid artinya tempat sujud, juga berarti tempat beribadah. Jika ditinjau dari sudut pandang etimologi akar kata dari masjid adalah sajada di mana sajada berarti sujud atau tunduk. Kata masjid sendiri berakar dari bahasa Aram. Kata masjid ditemukan dalam sebuah inskripsi dari abad ke 5 Sebelum Masehi. Kata masjid ini berarti "tiang suci" atau "tempat sembahan". Sama halnya dalam Kamus Bahasa ArabIndonesia karangan Mahmud Yunus menyebutkan bahwa masjid berasal dari kata "sajada" yang berarti membungkuk dengan khidmat. ${ }^{22}$ Sementara kata masjid dalam bahasa Inggris disebut mosque. Kata mosque ini berasal dari kata mezquita dalam bahasa Spanyol. Dan kata mosque kemudian menjadi populer dan digunakan dalam bahasa Inggris secara luas.

Dari pengertian di atas, seperti dikutip Abdul Basir, Sidi Gazalba memposisikan masjid bukan saja sebagai tempat ibadah berupa sholat semata, bahkan jauh lebih dari itu, masjid ternyata berfungsi juga untuk mengabdiakan diri kepada Allah SWT. Masjid sebagai tempat pengeabdian kepada Allah SWT termasuk di dalamnya sebagai tempat pengembangan ilmu pengetahuan dan kebudayaan. Karena sangat urgennya fungsi masjid ketika Rasulullah SAW dan Abu Bakar berhijrah dari kota Makkah ke kota Madinah, mereka singgah Quba pada tahun 622 M. Di desa ini mereka beristirahat selama beberapa hari dengan menginat di rumah Kalsum bin Hindun. Beliau pun membangun masjid di halaman rumah itu. Untuk merialisasikan program tersebut Nabi dan para sahabat bekerja bakti membangunnya. Akhirnya berdirilah sebuah bangunan masjid di Quba, dan inilah masjid Islam pertama dalam sejarah Islam. ${ }^{23}$

Selain tempat ibadah masjid juga merupakan pusat kehidupan komunitas muslim. Kegiatan-kegiatan perayaan hari besar, diskusi, kajian agama, ceramah dan belajar Al Qur'an sering dilaksanakan di Masjid. Bahkan dalam sejarah Islam di masa-masa awal, masjid turut memegang peranan dalam aktivitas sosial kemasyarakatan hingga kemiliteran.

${ }^{22}$ A.W. Munawwir, Kamus al-Munawwir Arab-Indosnesia (Surabaya: Pustaka Progressif, 1997), 610.

23M. Irawan, Keajaiban Masjid Nabawi (Indonesia: Spasi Media, 2014), 47.

Jurnal Pendidikan Agama Islam (Journal of Islamic Education Studies)

Volume 5 Nomor 2 (2017)

ISSN(p) 2089-1946\& ISSN(e) 2527-4511

Hal. 298 - 308 
Dalam Fathu al-Rahman disebutkan kata masjid dengan berbagai bentuk terulang sebanyak 25 kali. ${ }^{24}$ Sementara M. Quraish Shihab menyebutkan bahwa kata masjid terulang sebanyak dua puluh delapan kali di dalam Al-Quran yang dari segi bahasa, kata tersebut terambil dari akar kata sajada-sujud, yang berarti patuh, taat, serta tunduk dengan penuh hormat dan takzim. Meletakkan dahi, kedua tangan, lutut, dan kaki ke bumi, yang kemudian dinamai sujud oleh syariat, adalah bentuk lahiriah yang paling nyata dari makna-makna di atas. itulah sebabnya mengapa bangunan yang dikhususkan untuk melaksanakan shalat dinamakan masjid, yang artinya "tempat bersujud."25

Bila dilihat dalam rekaman sejarah ketika nabi Muhammad SAW memutuskan untuk hijrah, maka tampak jelas usaha yang dilkukan pertama oleh beliau sengaja mendirikan masjid. Hal ini bisa dijumpai dalam al-Qur'an surah atTaubah ayat 108, yaitu:

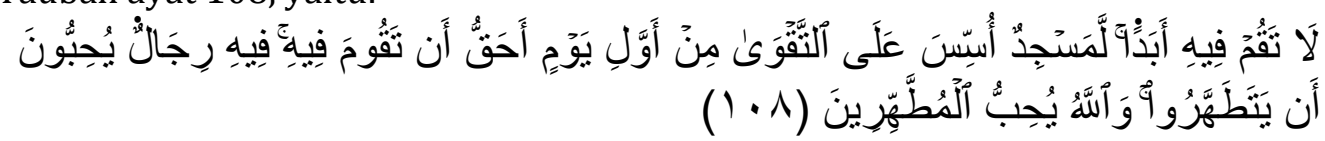

"Janganlah kamu bersembahyang dalam mesjid itu selama-lamanya. sesungguhnya mesjid yang didirikan atas dasar taqwa (mesjid Quba), sejak hari pertama adalah lebih patut kamu sholat di dalamnya. di dalamnya mesjid itu ada orangorang yang ingin membersihkan diri. dan Sesungguhnya Allah menyukai orangorang yang bersih."

Masjid pertama yang dibangun oleh Rasulullah Saw. adalah Masjid Quba' seperti yang disebutkan sebelumnya. kemudian disusul dengan Masjid Nabawi di Madinah. Selain kedua masjid Quba dan Nabawi terdapat satu masjid lagi yang cukup berserah di masa Nabi SAW yaitu masjid Qiblatain.

Masjid Qiblatain terletak sekitar $4 \mathrm{~km}$. arah barat laut Masjid Madinah. Masjid ini dinamakan dengan masjid Qiblatain karena pada saat Nabi shalat dhuhur dan baru dapat dua rakaat, Nabi mendapatkan wahyu yang memerintahkannya untuk mengubah kiblat ke arah ka'bah, maka Nabi berputar ke arah kabah, dan kemudian dinamakanlah masjid ini dengan masjid Qibalatain. Konstruksi bangunan masjid ini terbuat dari batu (labin), semacam batu bata, hanya saja tidak dipanaskan di tungku, tetapi dijemur. atap masjid ini terbuat dari pohon kurma (judzu'), daun kurma ( $s a^{\prime} a f$ ) dan pelepah kurma (jarid). ${ }^{26}$

24'Ilmi Jadah Fidhullah, Fathu al-Rahmān Li al Ṭalibiyāti al-Qur'ān (Indonesia: Diponegoro, tt), 204.

${ }^{25}$ M. Quraish Shihab, Wawasan al-Qur'an; Tafsir Maudhu'i atas Berbagai Persoalan Umat (Bandung: Mizan, 1996), 452.

${ }^{26}$ M. Syafi, "Bangunan Masjid Pada Masa Nabi dan Implikasinya Terhadap Jamaah Masjid Perempuan," Musãwa Jurnal Studi Gender dan Islam, Vol. 10 No. 1 (2011), 89-106. 
Terlepas dari perbedaan pendapat ulama tentang masjid yang dijuluki Allah sebagai masjid yang dibangun atas dasar takwa sebagaimana yang terdapat dalam ayat di atas, yang jelas bahwa keduanya Masjid Quba dan Masjid Nabawi dibangun atas dasar ketakwaan, dan setiap masjid seharusnya memiliki landasan dan fungsi seperti itu. Itulah sebabnya mengapa Rasulullah Saw meruntuhkan bangunan kaum munafik yang juga mereka sebut masjid, dan menjadikan lokasi itu tempat pembuangan sampah dan bangkai binatang, karena di bangunan tersebut tidak dijalankan fungsi masjid yang sebenarnya, yakni ketakwaan. AlQuran melukiskan bangunan kaum munafik itu sebagai berikut:

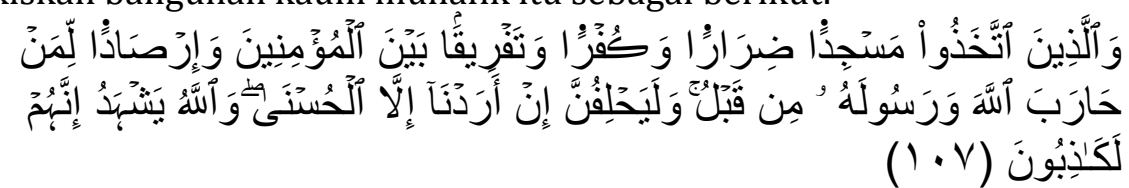

"Dan (di antara orang-orang munafik itu) ada orang-orang yang mendirikan masjid untuk menimbulkan kemudharatan (pada orang-orang mukmin), untuk kekafiran dan untuk memecah belah antara orang-orang mukmin serta menunggu kedatangan orang-orang yang Telah memerangi Allah dan rasul-Nya sejak dahulu. mereka Sesungguhnya bersumpah: "Kami tidak menghendaki selain kebaikan." dan Allah menjadi saksi bahwa Sesungguhnya mereka itu adalah pendusta (dalam sumpahnya)." (At-Taubah: 107)

Dalam tafsir al-Maraghi dijelaskan bahwa setelah Nabi menetap di Madinah dan orang mukmin orang munafik ingin membuat tipu muslihat atas kebijaksanaan Nabi mendirikan masjid. Sebab masjid yang didirikan Nabi dianggap melecehkan bagunan yang didirikan oleh nenek moyang mereka. Bahkan dalam satu riwayat Nabi memutuskan merunthkan bangunan mereka yang tidak didirikan atas ketakwaan kepada Allah. Seterusnya yang dimaksudkan ayat di atas dengan orang yang telah memerangi Allah dan Rasul-Nya dalam sejak dahulu ialah seorang pendeta Nasrani bernama Abu 'Amir Ar-Rahib ${ }^{27}$ yang mereka tunggu-tunggu kedatangannya dari Syiria untuk bersembahyang di masjid yang mereka dirikan itu, serta membawa tentara Romawi yang akan memerangi kaum muslimin. akan tetapi kedatangan abu 'Amir Ini tidak jadi Karena ia mati di Syiria. dan masjid yang didirikan kaum munafik itu diruntuhkan atas perintah Rasulullah s.a.w. berkenaan dengan wahyu yang diterimanya sesudah kembali dari perang Tabuk.

Maka semakin jelas terlihat bahwa kedudukan masjid bagi umat muslim sangat penting. Sebagaimana terlihat dalam keterangan di atas nabi sengaja meruntuhkan bagunan-bangunan orang-orang musyrik yang di dalamnya selalu dipraktekkan aktivitas kemakisatan. Sementara masjid itu jauh berbeda dengan

${ }^{27}$ Ahmad Mustafa al-Maraghi, Tafsir Al-Maraghi Juz al-Hadi 'Asyara (Mesir: Syirkatu Maktabah, 1946), 24.

Jurnal Pendidikan Agama Islam (Journal of Islamic Education Studies)

Volume 5 Nomor 2 (2017)

ISSN(p) 2089-1946\& ISSN(e) 2527-4511

Hal. 300 - 308 
apa yang mereka dirikan sebagaimana dijumpai dalam surah at-Taubah ayat 107 di atas tadi.

Dari dua masjid yang disebutkan pada ayat itu, masjid Nabawilah yang telah menjabarkan fungsinya sehingga lahir peranan masjid yang beraneka ragam. Sejarah mencatat tidak kurang dari sepuluh peranan yang telah diemban oleh Masjid Nabawi, yaitu sebagai berikut: (1) Tempat ibadah (shalat, zikir); (2) Tempat konsultasi dan komunikasi (masalah Ekonomi-sosial budaya); (3) Tempat pendidikan; (4) Tempat santunan sosial; (5) Tempat latihan militer dan persiapan alat-alatnya; (6) Tempat pengobatan para korban perang; (7) Tempat perdamaian dan pengadilan sengketa; (8) Aula dan tempat menerima tamu; (9) Tempat menawan tahanan; (10) Pusat penerangan atau pembelaan agama. ${ }^{28}$

Dari keterangan di atas, terlihat begitu besarnya peranan masjid ditengah-tengah masyarakat muslim pada masa klasik Islam. Masjid pada waktu itu jauh lebih besar dan bervariasi dibandingkan dengan fungsinya sekarang. Dulu, di samping sebagai tempat ibadah, masjid adalah lembaga pendidikan.

Barangkali, pada masa modern ini, orang meragukan masjid sebagai lembaga pendidikan. Tetapi itu dapat ditepis dengan mengetengahkan sejarah yang menunjukkan bahwa fungsi masjid sebagai lembaga pendidikan menjukkan prestasi yang cukup pesat. Sebagaimana dapat dilihat pada masa masa Khalifah Umar bin Khattab, dapat dijumpai sejumlah tenaga pengajar yang secara resmi diangkat oleh khalifah untuk mengajar di masjid-masjid, misalnya di Kufah, Basrah, dan Damaskus. Atas dasar inilah Sayyed Hussein Nasr sebagai dikutif Hasan Asari menyimpulkan bahwa masjid mulai berfungsi sebagai sekolah pada masa khalifah kedua. ${ }^{29}$

Atas pendapat yang dikemukakan oleh Sayyed tersebut menunjukkan bahwa pada masa Nabi waktu hidup dan khalifah pertama Abu Bakar lembaga pendidikan dalam masjid masih bersifat sederhana. Misalnya merupakan suatu tradisi Rasulullah SAW duduk di masjid Nabawi (Madinah) guna memberikan pelajaran kepada para sahabat mengenai masalah-masalah keagamaan dan duniawi. ${ }^{30}$

Kemudian perkembagan masjid sebagai lembaga pendidikan Islam mulai menjamur pada abad ke-9 sebagaimana Hasan Ashari mengutip dari beberapa tokoh menyebutkan kota Baghdad saja memiliki tidak kurang dari 3.000 bangunan masjid, al-Iskandariyah mempunyai sekitar 12.000 masjid, di Maskus juga terdapat 500 masjid yang diketahui secara pasti. Angka-angka yang

\footnotetext{
${ }^{28}$ Shihab, Wawasan al-Qur'an, 455-456.

${ }^{29}$ Hasan Asari, Menyingkap Zaman Keemasan Islam (Bandung: Cita Pustaka Media, 2007), 44.

${ }^{30}$ M. Atiyah al-Abrasyi, Dasar-dasar Pokok Pendidikan Islam (Jakarta: Bulan Bintang, 1993), 58.
} 
diberikan oleh para pakar tersebut menunjukkan bahwa praktek pendidikan dalam lembaga yang formal berbentuk masjid sangatlah besar. ${ }^{31}$ Itulah sebabnya pada masa awal itu pendidikan tidak bisa dilepaskan dari masjid, karena merupakan tempat yang vital untuk mengembangkan budaya Islam juga lingkaran studi umat dan tempat yang suci. ${ }^{32}$ Akan tetapi, dengan perkembangan wilayah umat Islam yang semakin luas dan permbangan ilmu pengetahuan pasca wafatnya Rasulullah sampai tegaknya khalifah Umaiyah yang kemudian digantikan khalifah-khalifah Bani Abbasiyah posisi masjid sebagai lembaga pendidikan mengalami perkebangan misalnya didirikannya Masjid Jami' yang dikelola oleh para khalifah atau didirikan oleh orang lain atas izin dari pemerintah. ${ }^{33}$

Jadi masjid dan Masjid Jami' fungsinya memang sama-sama tempat ibadah, tetapi ada yang berbeda juga di antara keduanya terutama dalam soal keluasan pegaruhnya. Masjid Jami' lebih berpegaruh dibanding masjid. Kemudian Masjid Jami' segala sesuatunya mulai dari pendirian, perawatan, gaji staf, imam, syekh, muazzin, dan sebagainya diurus oleh pemerintah, sementara masjid lebih tergantung pada wakaf dan sedekah secara natural dan dapat menentukan arah kegiatan sendiri. ${ }^{34}$ Perkembangan masjid sebagai lembaga pendidikan selain masjid dan masjid jami' juga terdapat istilah masjid-khan yaitu masjid yang dilengkapi dengan sebuah asrama bagi orang yang menuntut di sana. ${ }^{35}$

Fenomena sejarah tentang masjid yang sudah dipaparkan di atas membuktikan bahwa masjid betul-betul lembaga yang cukup aktual pada masa itu untuk proses pendidikan. Namun keadaan itu mulai berubah seiring perkmbangan berbagai ilmu pengetahuan dan pemikiran sehingga mengharuskan lembaga pendidikan dibangun dalam bentuk yang lebih modren dengan menggunakan lembaga yang berbentuk klasikal dan dilengkapi dengan fasilitas yang lebih mapan.

Di Indonesia sendiri masjid menjadi icon umat muslim. Terhitung pada tahun 2017 masjid di Indonesia mencapai 800 ribu. Jumlah yang cukup pantastis ini membuat setiap orang terkejut, bahkan Raja Salman sendiri di sela-sela kunjungan di Indonesia pada tahun 2017 awalnya beranggapan masjid di Indonesia sekitaran 8000 masjid, tetapi begitu Wakil Presiden Indonesia Jusuf

\footnotetext{
${ }^{31}$ Al-Abrasyi, Dasar-dasar Pokok Pendidikan Islam, 45.

32 Roqib, Ilmu Pendidikan Islam, 142.

${ }^{33}$ Asari, Menyingkap Zaman Keemasan Islam, 46.

${ }^{34}$ Asari, Menyingkap Zaman Keemasan Islam, 47.

${ }^{35}$ Haidar Putra Daulay, Sejarah Pendidikan Islam (Medan, IAIN Press Medan, 2007), 52.

Jurnal Pendidikan Agama Islam (Journal of Islamic Education Studies)

Volume 5 Nomor 2 (2017)

ISSN(p) 2089-1946\& ISSN(e) 2527-4511

Hal. 302 - 308
} 
Kalla yang juga sebagai Ketua Dewan Masjid Indonesia menerangkan bahwa jumlah masjid di Indonesia 800 ribu Raja Salman pun sesaat terkejut. ${ }^{36}$

Sebagai fungsi utama, masjid di Indonesia tetap digunakan sebagai tempat ibadah bagi kaum muslim. Namun sebagai tempat pendidikan masjid di Indonesia cukup variatif. Artinya tidak semua masjid di Indonesia dapat menjalankan program terkait dengan pendidikan, sebab program pendidikan di masjid butuh biaya yang memadai. Biasanya masjid yang memiliki rutinitas pendidikan adalah masjid agung di sebuah Kabupaten, Kota, Provinsi dan Pusat. Selain itu ada juga masjid-masjid besar yang memiliki jama'ah ramai atau masjid yang dibangun dari infaq/wakaf orang kaya dan orang kaya tersebut sekaligus menjadi donatur masjid tersebut. Walaupun begitu program pendidikan di masjid pada skala nasional tetap menjadi salah satu program unggulan. Hal ini dapat diketahui dari sosialisasi program unggul masjid pada acara pelantikan Pengurus Pusat Dewan Masjid Indonesia (DMI) di Masjid Istiqlal, Jakarta pada Jum'at 12 Januari 2018.

\section{E. Lembaga Pendidikan Islam Modern di Masa Rasulullah SAW}

\section{Kuttab}

Kuttab telah dikenal dikalangan bangsa Arab pra-Islam, di mana fungsinya sama setelah kuttab berakultrasi dengan Islam. ${ }^{37}$ Adapun istilah $k u t t a b$ sendiri yang kemudian populer sebagai institusi pendidikan berasal dari kata "taktib" yang berarti belajar menulis, dan belajar menulis itulah fungsinya kuttab". Kebiasaan dan kemampuan membaca dan menulis telah berkembang di kalangan masyarakat Arab pra-Islam, meskipun masih pada tataran minimal. Sehingga, ketika Islam datang potensi penting ini mendapatkan daya dorong baru. Pada awalnya, mayoritas pengajarnya adalah orang non-muslim, khususnya Yahudi dan Nasrani. Namun seiring bergulirnya waktu, jumlah ummat Islam yang menguasai keterampilan membaca dan menulis meningkat pesat. Sehingga kuttab tidak lagi mengajarkan membaca dan menulis Al-Qur'an.

Ahmad Syalabi, berpendapat ada dua corak pendidikan dalam kuttab yaitu pada masa-masa awal pertumbuhan dan perkembangan Islam, yakni mengajarkan tulis baca dan mengajarkan al-Qur'an pada tingkat dasar. ${ }^{38}$

\footnotetext{
36Tribun Jawa Tengah, dalam http://jateng.tribunnews.com/2017/03/04/raja-salmanterkejut-begitu-tahu-jumlah-masjid-di-indonesia. Diiakses pada 01 Oktober 2017.

${ }^{37}$ Asari, Menyingkap Zaman Keemasan Islam, 24.

${ }^{38}$ Ahmad Syalabi, Sejarah Kebudayaan Islam (Jakarta: Al-Husna, 1997), 35-38.
} 
Perbedaan ini seperti disebutkan Hasan Asari terutama didasarkan atas isi pengajaranya, tenaga pengajar, dan masa tumbuhnya. ${ }^{39}$

Untuk lebih rincinya perbedaan itu, pada kuttab jenis pertama berfungsi mentransformasikan tulis baca dengan teks dasar puisi-puisi Arab serta sebagian besar gurunya adalah Non-Muslim. Perlu diketahui kuttab jenis pertama ini meski pengajarnya didominasi oleh orang-orang dzimmi, tetapi Nabi Muhammad SAW juga memerintahkan beberapa sahabat seperti al Hakam Ibn Sa'id untuk mengajar pada kuttab tersebut. Sementara jenis kedua adalah tempat belajar yang sudah masuk pada ranah pengajaran al-Qur'an dan dasar-dasar ajaran agama Islam. Pada awalnya jenis kedua ini sama dengan jenis pertama, tetapi seiring dengan waktu, kuttab jenis kedua ini lahir sebagai jawaban dari perkembangan Islam pada waktu itu. Sehingga pengajaran al-Qur'an dan ajaran agama diberikan di sana di mana sebelumnya hanya diberikan atau diajarkan di Masjid dan di rumah-rumah.

2. Suffah

Pada masa Islam klasik lembaga pendidikan juga terdiri atas suffah. Suffah adalah suatu tempat yang digunakan untuk aktivitas pendidikan biasanya tempat ini menyediakan pemondokan bagi pendatang baru dan mereka yang tergolong miskin. Di sini para siswa diajari membaca dan menghafal al-Qur'an secara benar dan hukum Islam di bawah bimbingan langsung dari Nabi, dalam perkembangan berikutnya, sekolah suffah juga menawarkan pelajaran dasar-dasar menghitung, kedokteran, astronomi, geneologi dan ilmu filsafat. ${ }^{40}$

Sementara Ubaidillah menyebutkan bahwa Al Suffah merupakan ruang atau bangunan yang bersambung dengan masjid. Suffah dapat dilihat sebagai sebuah sekolah karena kegiatan pengajaran dan pembelajaran dilakukan secara teratur dan sistematik. Contohnya Masjid Nabawi yang mempunyai suffah 16 yang digunakan untuk majelis ilmu. Lembaga ini juga menjadi semacam asrama bagi para sahabat yang tidak atau belum mempunyai tempat tinggal tetap. Mereka yang tinggal di suffah ini disebut ahl al suffah dan biasanya jumlah mereka kurang lebih 70 orang sahabat. ${ }^{41}$ Ada juga yang berpendapat bahwa suffah sebagai teras yang luas dan tinggi atau boleh juga bermakna tempat berteduh, dan teras rumah. Tetapi yang pasti Suffah adalah tempat berteduh di Masjid Nabawi selama masa kenabian setelah hijrah. Kaum miskin Muhajirin menjadikannya sebagai tempat tinggal.

Ahl al-Suffah ini terdiri dari para sahabat Rasulullah SAW yang tergolong fakir dan tidak memiliki keluarga. Mereka tinggal menetap di sudut

\footnotetext{
${ }^{39}$ Asari, Menyingkap Zaman Keemasan Islam, 26.

40 Heri Hidayat, "Teologi Lembaga Pendidikan Islam," Ijtimaiyya, Vol. 6 No. 2 (2013), 115-142.

${ }^{41}$ Ubaidillah, "Pengelolaan Lembaga Pendidikan pada Masa Rasulullah Saw," Al-Ittihad, Vol. 2 Vol. 1 (2016).
} 
Masjid Nabawi yang difungsikan sebagai tempat belajar membaca dan memahami agama Islam. Di sana mereka juga mengkaji dan mempelajari AlQur'an. Suffah ini menawarkan pendidikan bukan hanya untuk para pemondok, tetapi juga untuk pengunjung pada saat itu yang cukup banyak jumlahnya. Dari waktu ke waktu, jumlah penghuni suffah ini berubah-ubah. Menurut sebagian ahli, suffah ini dianggap sebagai universitas Islam pertama (the first Islamic university) ${ }^{42}$ dalam pengertian formal. Disebut suffah sebagai lembaga bercirikan formal cukup beralasan, sebab di suffah ini pembelajaran dilakukan secara berkesinambungan dan sangat terarah, di mana Nabi SAW langsung menjadi guru bagi mereka.

Di Indonesia, model suffah ini berubah fungsi, di mana masjid tetap ada tempat yang dibuatkan persis disudut samping kiri atau kanan masjid. Tetapi fungsinya hanya sebagai tempat tingggal bagi gharim masjid. Gharim ini adalah petugas masjid yang menjaga dan mengisi sholat lima waktu. Sementara lembaga pendidikan dibuatkan di sekitar masjid. Lembaga ini disebut dengan Madrasah Diniyah Ta'miliyah Awwaliyah (MDTA). Di beberapa kota besar, seperti Pekanbaru masjid sudah banyak yang memiliki lembaga pendidikan MDTA yang menyatu di kawasan masjid itu sendiri. MDTA ini merupakan tempat belajar agama bagi anak-anak usia SD. Bahkan lebih dari itu, masjid Agung An-Nur memiliki program pendidikan yang diselenggarakan secara formal mulai dari PAUD, TK, MDA, SD, SMP dan SMA.

Berdirinya lembaga pendidikan di sekitar masjid apabila direnungkan terlihat hampir sama dengan suffah. Fungsinya sama-sama tempat yang digunakan untuk transformasi nilai-nilai agama. Hanya saja suffah lebih historis dan semangat pendiriannya hanyalah untuk menampung para orangorang yang kurang mampu secara ekonomi, sebab mereka adalah orang yang datang dari Makkah dengan meninggalkan harta di sana. Kiranya perlu penelitian serius untuk melihat apakah pendirian lembaga pendidikan di kawasan masjid di Indonesia ada kaitannya langsung dengan fakta sejarah pendirian suffah sebagai tempat tinggal dan sekaligus menjadi tempat belajar.

Sungguhpun begitu, perkembangan masjid dengan mengasuh lembaga pendidikan di sekitarnya patut diapresiasi dan seyogyanya dapat ditingkatkan di seluruh daerah. Model seperti ini cukup potensial untuk mengembangkan pendidikan agama Islam bagi para generasi muda. Selain untuk kelangsungan kemajuan Islam itu sendiri, negara pun pasti akan terbantu. Sebab Negara terkadang belum sanggup untuk menjamah daerah Indonesia yang begitu luas. Oleh sebab itu, pemerintah seharusnya mengapresiasi umat Islam karena telah membantu menyeleasikan agenda-agenda krusial Negara, termasuk salah satunya agenda pendidikan.

${ }^{42}$ Ubaidillah, "Pengelolaan Lembaga Pendidikan pada Masa Rasulullah Saw". 


\section{F. Kesimpulan}

Dari berbagai argumentasi yang dikemukakan di atas, maka ditemukan bahwa rumah tangga sebagai lembaga pendidikan adalah lembaga pertama yang terdapat dalam dunia Islam. Adalah rumah Arqam yang dijadikan Nabi pertama kali sebagai tempat menyampaikan pesan-pesan kenabian kepada sahabat. Rumah merupakan tempat yang sudah ada sebelum Islam datang, tetapi Nabi memberi isyarat bahwa rumah tangga juga menjadi bahagian pendidikan dan sangat penting dalam kehidupan anak. Barulah kemudian masjid, selain tempat Ibadah masjid juga menjadi lembaga pendidikan yang cukup dominan di masa $\mathrm{Nabi}$, walaupun seiring perkembangan zaman masjid agak kurang intesitasnya dalam hal pendidikan disebabkan ada lembaga-lembaga yang dibangun khsusu pendidikan. Tetapi yang paling terpenting adalah masjid sampai saat ini masih memiliki fungsi pendidikan, dan ini harus benar-benar ditingkat demi kemajuan Islam.

Lembaga berikutnya adalah suffah, yang merupakan inisiatif Rasulullah SAW untuk para sahabat yang hijrah dengan tidak memiliki harta-harta atau masuk kategori miskin. Suffah selain tempat tinggal bagi mereka juga menjadi tempat belajar, bahkan Nabi sendiri yang mejadi guru bagi mereka. Orang yang tinggal di Suffah ini hidupnya sangat sederhana dan mereka adalah ahli ibadah. Terakhir tempat atau lembaga yang banyak berkontribusi terhadap keberhasilan dakwah nabi Muhammas SAW adalah Kuttab. Kuttab ada dua jenis, pertama digunakan untuk mengajar baca-tulis, sendangkan yang kedua adalah untuk belajar Al-Qur'an dan ajaran-ajaran Islam lainnya. Kuttab jenis kedua lahir sebagai jawaban atas pentingnya lembaga yang lebih representatif dalam mengajarkan ilmu-ilmu agama kepada para sahabat. Jadi, ini membuktikan bahwa Islam sangat visioner terkait dengan pendidikan. Kontribusi lembaga pendidikan Islam selain mampu menciptakan perubahan mendasar dalam konteks keagamaan dan kehidupan sosial, lembaga pendidikan Islam juga menjadikan Islam sebagai agama yang terbuka (inkulsif) terhadap perubahan zaman selama tidak bertetangan dengan aqidah.

\section{G. Referensi}

Abrasyi (al), M. Atiyah. Dasar-dasar Pokok Pendidikan Islam. Jakarta: Bulan Bintang, 1993.

Ali, Mohammad Daud. Pendidikan Agama Islam. Jakarta: Raja Grafindo Persada, 1998.

Asari, Hasan. Hadis-hadis Pendidikan; Sebuah Penelusuran Akar-akar Ilmu Pendidikan Islam. Bandung: Cita Pustaka, 2008. 

2007.

Menyingkap Zaman Keemasan Islam. Bandung: Cita Pustaka Media,

Daulay, Haidar Putra. Sejarah Pendidikan Islam. Medan: IAIN Press Medan, 2007.

Fidhullah, Ilmi Jadah. Fathu al-Rahmān Li al Talibiyāti al-Qur'ān. Indonesia: Diponegoro, $\mathrm{tt}$.

Harahap, Musaddad. "Esensi Peserta Didik dalam Perspektif Pendidikan Islam." Al-Thariqah: Jurnal Pendidikan Agama Islam, Vol. 1 No. 2 (2017).

Hasan (al), Muhammad Yusuf. Pendidikan Anak Dalam Islam. Jakarta: Kalam Mulia, 2001.

Hidayat, Heri. "Teologi Lembaga Pendidikan Islam." Ijtimaiyya, Vol. 6 No. 2 (2013).

Irawan, M. Keajaiban Masjid Nabawi. Indonesia: Spasi Media, 2014.

Langgulung, Hasan. Asas-asas Pendidikan Islam. Jakarta: Pustaka al-Husna, 1992, Cet. II.

Maraghi (al), Ahmad Mustafa. Tafsir Al-Maraghi, Juz 28. Mesir: Syirkatu Maktabah, 1946.

Syirkatu Maktabah, 1946.

Tafsir Al-Maraghi Juz. al-Hadi 'Asyara. Mesir:

Mujib, Abdul, dan Mudzakkir, Jusuf. Ilmu Pendidikan Islam. Jakarta: Kencana: 2008.

Munawwir, A.W. Kamus al-Munawwir Arab-Indosnesia. Surabaya: Pustaka Progressif, 1997.

Nasional, Departemen Pendidikan. Kamus Besar Bahasa Indonesia. Jakarta: Pusat Bahasa, 2008.

Ramayulis. Ilmu Pendidikan Islam. Jakarta: Kalam Mulia, 2006.

Roqib, Moh. Ilmu Pendidikan Islam; Pengembangan Pendidikan Integratif di Sekolah, Keluarga, Masyarakat. Yokyakarta: LKiS, 2009.

Salim, Hadiyah. Terjemahan Mukhtarul Hadits Sayyid Ahmad Al-Hasyimi. Bandung: Al-Ma'arif, 1980.

Shihab, M. Quraish. Wawasan al-Qur'an; Tafsir Maudhu'i Atas Berbagai Persoalan Umat. Bandung: Mizan, 1996.

Siregar, Lina Mayasari. "Upaya Pendidikan Islam Pada Masa Awal Nabi Muhammad SAW." Al-Thariqah: Jurnal Pendidikan Agama Islam, Vol. 1 No. 1 (2017). 
Musaddad Harahap \& Lina Mayasari Siregar

Syafi, M. "Bangunan Masjid Pada Masa Nabi Dan Implikasinya Terhadap Jamaah Masjid Perempuan." Musãwa Jurnal Studi Gender dan Islam, Vol. 10 No. 1 (2011).

Syalabi, Ahmad. Sejarah Kebudayaan Islam. Jakarta: al-Husna, 1997.

Taubah, Mufatihatut. "Pendidikan Anak dalam Keluarga Perspektif Islam." Jurnal Pendidikan Agama Islam (Journal of Islamic Education Studies), Vol. 3 No. 1 (2016).

Thabari (al), Ja'far Muhammad bin Jarir. Tafsir al-Thabar Juz. Atssaminu 'Asyara. Badar Hijr: Ath-Taba'ah wa al-Nasir wa al-Taji'u wa al-I'lan, 2001.

Thalib, M. 50 Pedoman Mendidik Anak Menjadi Shalih. Bandung: Irsyad Baltus Salam, 1996.

Ubaidillah. "Pengelolaan Lembaga Pendidikan Pada Masa Rasulullah SAW." AlIttihad, Vol. 2 No. 1 (2016).

http://jateng.tribunnews.com/2017/03/04/raja-salman-terkejut-begitu-tahujumlah-masjid-di-indonesia. 